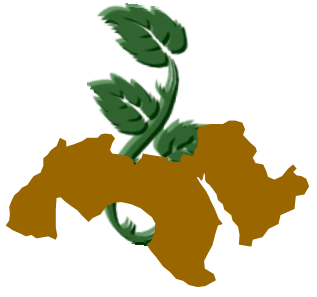

Arab Univ.

J. Agric. Sci., Ain Shams Univ., Cairo, 18(1), 65-76, 2010

\title{
SELENIUM INDUCES ANTIOXIDANT DEFENSIVE ENZYMES AND PROMOTES TOLERANCE AGAINST SALINITY STRESS IN CUCUMBER SEEDLINGS (Cucumis sativus)
}

\author{
Walaa $^{1}$, A. El-Shalakany; M.A. Shatlah ${ }^{1}$; M.H. Atteia ${ }^{1}$ and H.A.M. Sror ${ }^{1}$ \\ 1- Department of Agricultural Biochemistry, Faculty of Agriculture, Ain Shams University, \\ 68 Hadayek Shoubra, 11241, Cairo, Egypt
}

Keywords: Selenium, Salinity stress, Cucumber, Antioxidant enzymes and Phenylalanine ammonia-lyase

Abbreviations: Se, Selenium; ROS, Reactive oxygen species; APX, Ascorbate peroxidase; CAT, Catalase; PAL, Phenylalanine ammonia-lyase; EDTA, Ethylenediamine tetra acetic acid; MDA, Malondialdehyde; POD, Peroxidase; PVP, Polyvinylpyrrolidone; SOD, Superoxide dismutase; TBA, Thiobarbituric acid; TCA, Trichloroacetic acid; NBT, Nitroblue tetrazolium; P5CR, $\Delta^{1}$ Pyrroline-5-carboxylate reductase; P5CS, $\Delta^{1}$-Pyrroline-5-carboxylate synthetase. OAT, Ornithine- $\delta$ aminotransferase; $\quad \mathrm{P} 5 \mathrm{CDH}, \quad \Delta^{1}$ Pyrroline-5-carboxylate dehydrogenase and $\mathrm{PDH}$, Proline dehydrogenase; Poly acrylamide gel electrophoresis (PAGE)

\section{ABSTRACT}

Selenium (Se) is not an essential nutrient for higher plants. Although, it is able to induce stress tolerance in many plant species. The present study was carried out to investigate the ability of Se to promote the tolerance of cucumber seedlings to salinity stress and to identify some biochemical parameter associated with Se-induced resistance in cucumber seedlings. Plants were irrigated with 2000 ppm $\mathrm{NaCl}$ after treatment with 1ppm Se for two weeks and samples collected after 7 days from started salt-treatment. The biochemical changes due to treatment with $\mathrm{Se}$ and /or $\mathrm{NaCl}$ were monitored by determination of lipid peroxidation (LPO), proline, phenolic compounds and percentage of electrolyte leakage (EL) from plant tissues. Moreover, the activities of peroxidase (POD), ascorbate peroxidase (APX), catalase (CAT), superoxide dismutase (SOD) and phenylalanine ammonialyase (PAL) were determined. The treatment of cucumber seedling with salinity $(2000 \mathrm{ppm} \mathrm{NaCl})$ in the presence or absence of selenium caused a remarkable elevation in free proline concentration and the level of phenolic compounds. Salinity stress caused a high level of lipid peroxidation which led to increase the percentage of electrolyte leakage from plant tissues. Se treatment caused a significant reduction in electrolyte leakage and malondialdehyde concentration of cucumber seedlings. The specific activities of antioxidant enzymes (POD, SOD, and APX) and PAL were significantly increased by the treatment with $\mathrm{NaCl}$. Also, Se caused a significant elevation in the specific activities of POD, CAT, SOD, APX and PAL in cucumber seedlings grown under salt stress condition. On the other hand, Se caused a significant decrease in SOD activity in cucumber seedlings grown in non-salty condition. The isoenzymes pattern of POD demonstrated that peroxidase was upregulated by $\mathrm{Se}$ either in control or $\mathrm{NaCl}$-treated seedlings. The results concluded that Se induce six POD isoenzymes in cucumber seedlings. Se reduces and overcomes the oxidative injury caused by salinity stress. Moreover, the protective effect of Se against salinity stress may be carried out through a mechanism included activation of PAL which is responsible for phenolic compounds biosynthesis. The accumulation of these phenolic compounds in Se-treated seedling leads to a high activities of antioxidant defensive enzymes and increase the tolerance level towards salinity stress. 


\section{INTRODUCTION}

Soil salinity stresses plants in two ways. High concentration of salts in the soil makes it harder for roots to extract water and high concentration of salts within the plants can be toxic. Salts on the outside of roots have an immediate effect on cell growth and associated metabolism; toxic concentration of salts take time to accumulation inside plants before they affected plant function. Salinity is one of the major environmental factors that limiting global crop productivity. When plants subjected to salinity stress, the cretical balance between the formation of active oxygen species (AOS) and quenching activity of the antioxidant was disturbed. AOS generated due to salinity stress unbalances the cellular redox system in favor of oxidized forms resulting in oxidized damage to lipids, proteins and nucleic acids (Halliwell and Gutteridge 1989). Cucumber (Cucumis sativus L.) is one of the major vegetable crops grown in Egypt under the greenhouses conditions. Cucumber is a sensitive plant to oxidative stress (Janoudi and Widders 1993). So, we taken it in our study. Plant growth is limited by different unfavorable environmental conditions among which salt stress is considered to be one of the most important worldwide agricultural problems. High salinity can cause hyperosmotic stress and ion disequilibrium in plant cells, producing oxidative stress (Hasegawa et al 2000; Zhu 2001) and reducing plant growth. Also, many biotic and abiotic stresses induce an oxidative damage in plant cells. However, exposure of plants to salinity, drought, chilling or plant pathogens enhanced the production of reactive oxygen species (ROS) in plant cells (OImos et al 1997; Fieldes and Gerhardt 1998; Smirnoff 1993; Alscher et al 1997; Yordanov et al 2000; and Egert and Tevini 2002). The enhanced production of reactive oxygen radicals is responsible for peroxidation of membrane lipids, photosynthetic pigments, protein and nucleic acids (Smirnoff 1993; Alscher et al 1997; and Yordanov et al 2000). The oxidative damage of the important molecules in plant cells affect most of the physiological process in plants and caused cell death. Many plants protect themselves by enhancement of the level of antioxidant such as carotenoids, ascorbic, $\alpha$-tocopherol, flavonoids and phenolic compounds (Egert and Tevini 2002). Also, plants can tolerate the generation of ROS by enhancing antioxidative enzymes such as peroxidase, catalase and superoxide dismutase (Egert and Tevini 2002; Siegel 1993 and Sancho et al 1996). The hypothesis that selenium can pro- tect plants against salinity stress was tested previously. Se-hyper accumulator plants such as indian mustard, cabbage and broccoli can tolerate the oxidative stress and have high level of resistance against wide range of biotic and abiotic stress (Trelease and Trelease (1990) and Zhou 1990). Moreover, the protective effect of Se on plants has been demonstrated as a decrease in lipid peroxidation and an increase in the activity of antioxidant enzymes in Cd-stressed in rape seedlings (Filek et al 2007). In addition Se may activate disproportion of superoxide radical and thus reduce the need of their scavenger superoxide dismutase (SOD) (Hartikainen et al 2000). Many reports suggested that $\mathrm{Se}$ is able to promote plant growth and induce stress tolerance against salt stress in sorrel seedlings (Kong et al 2005), UV-irradiation and senescence related stress in lettuce (Hartikainen et al 1997; Hartikainen and Xue 1999; Xue and Hartikainen et al 2000 and Pennanen et al 2002), UV-induce stress in reygrass (Hartikainen et al 2000) and photo oxidative stress in potato (Seppänen et al 2003). Phenylalanine ammonialyase (PAL) is considered to be a key enzyme of the phenylpropanoid biosynthesis (Kacperska 1993), catalyzing the transformation of LPhenylalanine into trans-cinnamic acid, which is the prime intermediate in the biosynthesis of phenolic compounds (Dixon et al 1992 and Levine et al 1994). The activity of PAL was found to increase due to thermal stress (Kacperska 1993; Levine et al 1994 and Leyva et al 1995). PAL is considered to play a significant role in the mechanisms of stress acclimation in plant.

The main objective of the present investigation is to evaluate the protective effect of Selenium against salinity stress in cucumber seedlings and try to correlates the Se-induced salinity tolerance in cucumber seedlings with the activities of antioxidant defensive enzymes. The ability of Se to increase the phenolic compound biosynthesis through the activation of phenylalanine ammonialyase (PAL) was also studied.

\section{MATERIALS AND METHODS}

\subsection{Plant material and growth condition}

Cucumber seeds (Cucumis sativus, L. cv Zena) were cultivated in pots with sandy soil in a greenhouse for ten days (day by day). After germination, the seedlings (32-old days) were divided into two groups; the first group was irrigated with Hoagland's nutrient solution for two weeks, while, the second group was irrigated with the same nutrient 
solution containing $1 \mathrm{ppm} \mathrm{Se}$ in form of sodium selenite for 2 weeks. Each group was subdivided into two subgroups. One of them was irrigated with $\mathrm{NaCl}$ solution (2000 ppm) and the other irrigated with distilled water as control. After 7 days of salinity treatment, samples from all groups were collected and used for determination of fresh weight, dry weight and electrolyte leakage. Samples also were frozen at $-20^{\circ} \mathrm{C}$ and analysis was carried out.

\subsection{Moisture content}

Moisture content of cucumber seedlings was determined as recommended by A.O.A.C. (1975). A known weight of cucumber seedling was dried in a ventilation oven at $70^{\circ} \mathrm{C}$ for 24 hours, then at $105^{\circ} \mathrm{C}$ for three hours. The results were calculated per grams for each $100 \mathrm{~g}$ fresh sample.

\subsection{Measurement of electrolyte leakage}

The electrolyte leakage was measured according to the method described by (Kong et al 2005). Twenty leaf discs from each subgroup were excised and rinsed thoroughly with double distilled water to remove contamination caused by sampling. Samples were then transferred to tubes with $20 \mathrm{ml}$ double distilled water. The electrical conductivity $\left(E_{0}\right)$ of the solution was immediately measured using an electrical conductivity meter (DDSJ$308 \mathrm{~A}$, Shanghai) at $25^{\circ} \mathrm{C}$. The tubes were incubated at $30^{\circ} \mathrm{C}$ for $30 \mathrm{~min}$, and the electrical conductivity $\left(E_{1}\right)$ measured again. Subsequently, the tubes were placed in boiling water bath for $20 \mathrm{~min}$ and the electrical conductivity $\left(E_{2}\right)$ read after the tubes had cooled to $25^{\circ} \mathrm{C}$. The electrolyte leakage percentage (EL \%) of leaf cells was calculated in accordance to the following equation:

$$
E L(\%)=\left(E 1-E_{0}\right) /\left(E 2-E_{0}\right) \times 100
$$

\subsection{Lipid peroxidation}

The level of lipid peroxidation was measured by determination of malondialdhyde (MDA) in fresh seedling tissues as described by (Heath and Packer 1968). One gram of fresh seedling tissue was homogenized in $5 \mathrm{ml}$ of $0.1 \%(\mathrm{w} / \mathrm{v})$ TCA. The homogenate was centrifuged at $10000 \mathrm{x} g$ for 5 min, and then $4 \mathrm{ml}$ of thiobarbuteric acid $(0.5 \%$ in TCA $20 \%$ ) was added to $1 \mathrm{ml}$ of the supernatant. The mixture was heated to $95^{\circ} \mathrm{C}$ for $30 \mathrm{~min}$ and then quickly cooled in ice bath. The contents were centrifuged at 10000x g for $15 \mathrm{~min}$ and the absorbance of supernatent was measured at $532 \mathrm{~nm}$. The MDA content was calculated using a extinction coefficient of $155 \mathrm{mM}^{-1} \mathrm{~cm}^{-1}$. MDA content expressed as $\mu \mathrm{mol} . \mathrm{g}^{-1}$ fresh weight (FW).

\subsection{Determination of phenolic compound}

Phenolic compound were extracted from fresh seedling samples with ethanol $80 \%$. Total phenol content was determined in Shahidi and Naczk (1995). Using Folin-ciocalteus reagent at $725 \mathrm{~nm}$. Adding $1 \mathrm{ml}$ of each extract, $0.5 \mathrm{ml}$ Folin reagent and $7.5 \mathrm{ml}$ distilled water then shaking for 3 minutes then $1 \mathrm{ml} \mathrm{Na}_{2} \mathrm{CO}_{3}$ was added, the blue color developed was determined after $1 \mathrm{~h}$ at 725 $\mathrm{nm}$ against blank. The phenolic compound concentrations were determined by using the standard curve of catichol (100 ppm). The concentrations of phenolic compound were expressed as $\mu \mathrm{g} \cdot \mathrm{g}^{-1}$ dry weight (DW).

\subsection{Determination of free proline}

Free proline content of fresh seedling tissues was determined according to the method described by (Petters et al 1997). The proline content was expressed as $\mu \mathrm{g} \cdot \mathrm{g}^{-1}(\mathrm{FW})$.

\subsection{Preparation of crude enzyme extract}

Plant seedling $(500 \mathrm{mg})$ was homogenized in $1 \mathrm{ml}$ of chilled Potassium phosphate buffer (100 $\mathrm{mM}, \mathrm{pH} 7.0$ ) containing $0.1 \mathrm{mM}$ EDTA and $1 \%$ polyvinyl pyrrolidone (PVP) $(\mathrm{w} / \mathrm{v})$ at $4^{\circ} \mathrm{C}$. Homogenate was squeezed through four layers of cheese cloth and extract thus obtained was centrifuged at $15,000 \times \mathrm{g}$ for $15 \mathrm{~min}$ at $4^{\circ} \mathrm{C}$. Supernatant was used to measure the activities of POD, CAT, SOD, APX and PAL.

The protein content in the enzyme crude extracts was measured according to Lowry et al 1951.

\subsection{Assay of Peroxidase activity}

Peroxidase, POD (E.C 1.11.1.7) activity in enzyme crude extract was determined as described by (Hammer Schmidt et al 1982). The reaction mixture $(3 \mathrm{ml})$ consisted of $0.25 \%(\mathrm{~V} / \mathrm{V})$ Guaiacol in $10 \mathrm{mM}$ sodium phosphate buffer $(\mathrm{pH}=6.0$ containing $10 \mathrm{mM} \mathrm{H}_{2} \mathrm{O}_{2}$ ). $25 \mu \mathrm{l}$ of the crude enzyme extract was added to initiate the reaction. The absorption changes at $470 \mathrm{~nm}$ were followed by using spectrophotometrically (UV-visible-160A, Shimadzu). The activity was calculated by measuring the absorbance changes at $470 \mathrm{~nm}$ per min. A unit of peroxidase activity is defined as that amount of enzyme which cause $0.01 \Delta \mathrm{OD}$. $\mathrm{min}^{-1}$. The specific activity expressed as (IU. $\mathrm{mg}^{-1}$ protein).

\subsection{Assay of SOD activity}


Superoxide dismutase, SOD (E.C 1.15.1.1) activity was assayed by the method of (Beauchamp and Fridovich 1971) by measuring its ability to inhibit the photochemical reduction of nitro blue tetrazolium (NBT). The reaction mixture $(3 \mathrm{ml})$ contained $40 \mathrm{mM}$ phosphate buffer $(\mathrm{pH} 7.8), 13 \mathrm{mM}$ methionine, $75 \mu \mathrm{M}$ NBT, $2 \mu \mathrm{M}$ riboflavin, $0.1 \mathrm{mM}$ EDTA and $100 \mu \mathrm{l}$ of enzyme crude extract. The test tubes were shaken and placed $30 \mathrm{~cm}$ below light source consisting of $15 \mathrm{~W}$ fluorescent lamp. The absorbance was taken at 560 $\mathrm{nm}$. The activity of SOD was expressed as unit $\mathrm{mg}^{-1}$ protein. One unit of activity is the amount of protein required to inhibit $50 \%$ initial reduction of NBT under light and enzyme activity was expressed as unit's mg protein (IU. $\mathrm{mg}^{-1}$ protein).

\subsection{Assay of Catalase activity}

Catalase, CAT (E.C 1.11.1.6) activity was determined using a modified method developed by (Aeby 1984). The reaction mixture $(3 \mathrm{ml})$ contained $10 \mathrm{mM} \mathrm{H}_{2} \mathrm{O}_{2}$ and $100 \mu \mathrm{l}$ of enzyme extract in $50 \mathrm{Mm}$ phosphate buffer ( $\mathrm{pH} 7.0$ ). Enzyme activity was assayed by monitoring the decrease in absorbance at $240 \mathrm{~nm}$ as a consequence of $\mathrm{H}_{2} \mathrm{O}_{2}$ consumption. A unit of CAT activity $(U)$ is defined as the decomposition of $1 \mu \mathrm{mol}_{2} \mathrm{O}_{2}$ per min. CAT activity was expressed as unit's mg protein (IU. $\mathrm{mg}^{-1}$ protein).

\subsection{Assay of ascorbate peroxidase activity}

Ascorbate peroxidase, APX (E.C 1.11.1.11) activity was measured as a decrease in absorbance at $290 \mathrm{~nm}$ for $1 \mathrm{~min}$ using L-ascorbate as standard (Nakano and Asada 1981). The assay mixture 3 $\mathrm{ml}$ consisted of $0.5 \mathrm{mM}$ Ascorbic acid, $0.1 \mathrm{mM}$ $\mathrm{H}_{2} \mathrm{O}_{2}, 0.1 \mathrm{mM}$ EDTA, $50 \mathrm{mM}$ sodium phosphate buffer ( $\mathrm{pH}$ 7.0), and $100 \mu \mathrm{L}$ enzyme extract. A unit of APX activity is defined as the decreased of $1 \mu \mathrm{mol}$ of L-ascorbate per min and evaluated by comparison with a standard curve $(0.5 \mu \mathrm{mol}$ to $20 \mu \mathrm{mol}$ L-ascorbate). APX activity was expressed as unit's mg protein (IU. $\mathrm{mg}^{-1}$ protein).

\subsection{Assay of phenylalanine ammonia-lyase activity}

The activity of phenylalanine ammonia-lyase, PAL (E.C 4.3.1.5) was assayed by the method described by (He et al 2001). The PAL assay reaction consisted of $100 \mu \mathrm{L}$ crude enzyme extract and $900 \mu \mathrm{L}$ of $6 \mu \mathrm{mol}$ phenylalanine in $500 \mathrm{mM}$ Tris-
$\mathrm{HCl}$ buffer ( $\mathrm{pH} 8.5)$. The mixture was incubated at $37^{\circ} \mathrm{C}$ for $1 \mathrm{~h}$ and measured spectrophotometrically at $290 \mathrm{~nm}$. Absorbance at $290 \mathrm{~nm}$ was measured and the amount of trans-cinnamic acid formed was evaluated by comparison with a standard curve (0.067 $\mu \mathrm{mol} 0.1 \mathrm{ml}^{-1}$ trans-cinnamic acid). PAL activity was expressed as unit's mg protein $\left(\mu \mathrm{mol} \mathrm{h} \mathrm{h}^{-1}\right.$ $\mathrm{mg}^{-1}$ protein).

\subsection{Native PAGE \& Peroxidase isoenzyme}

The isozyme separation of POD was carried out in accordance to the method described by (Rao et al 1997). Equal amounts of protein (200 $\mu \mathrm{g})$ from each sample extract were mixed with loading buffer and subjected to continuous poly acrylamide gel electrophoresis (PAGE) under nondenaturing and non-reducing conditions. Samples were loaded in sets into gel after separation. The gels were stained with benzidine $(0.25 \mathrm{mg} / 100 \mathrm{ml}$ distilled water containing $0.5 \mathrm{ml}$ of glacial acetic acid) then added ten drops of $1 \%$ freshly hydrogen peroxide to POD isozyme pattern.

\section{Statistical analysis}

Results are presented as means values \pm standard deviasion of five replicates. Data were analsed by one way analysis of variance (ANOVA) using Student's t-test to test the different significance. Comparisons with $P$ - values of $p<0.05$ were considered significantly different.

\section{RESULTS}

Selenium induces growth of cucumber seedlings grown under salinity stress

Data in (Fig.1.A) indicated that salt treatment of cucumber seedlings for 7 days caused a significant reduction in the fresh weight. Moreover, the fresh weight of salt-stressed seedlings was decreased by about $36 \%$ of control fresh weight. While, Se-treatment caused a significant increase in the fresh weight of cucumber seedlings grown in the presence or absence of salinity stress by about $17 \%$ and $15 \%$ respectively.

Also, (Fig.1.B) indicated that salt treatment of cucumber seedlings for 7 days caused a slight decrease in dry weight. Moreover, the dry weight of salt-stressed seedlings were decreased by about $14 \%$ of control dry weight. Under 2000 ppm NaCl stress condition, cucumber seedlings treated with $1 \mathrm{ppm} \mathrm{Se}$ in form of selenite grew better than control. The results indicated that selenium at concentration of $1 \mathrm{ppm}$ significantly promote the growth of salt-stressed and non salt-stressed cucumber 
seedlings. Where, the seedling dry weight of selenium treated cucumber seedlings grown in the presence or absence of salt stress condition exhibited the maximum dry weight by about $73 \%$ and $53 \%$ of control respectively.

(A)

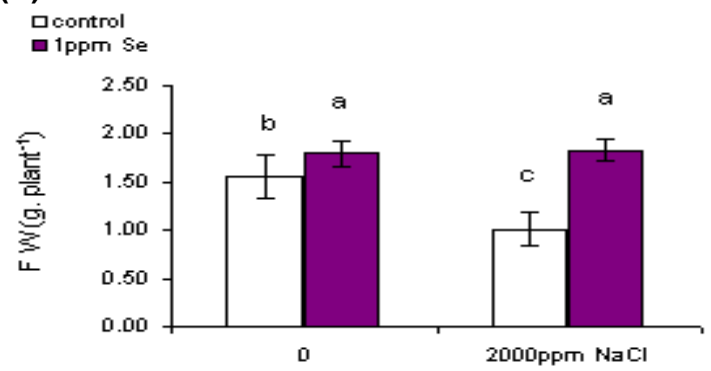

(B)

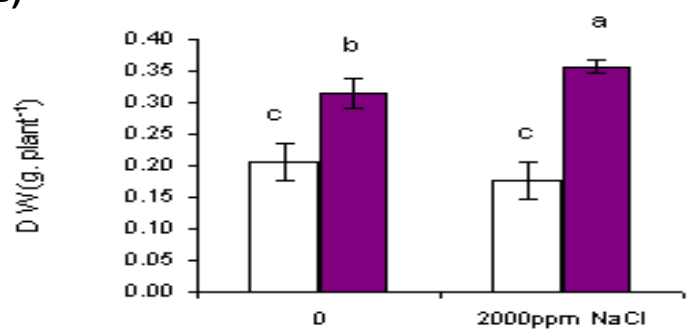

Fig. 1. Effects of Se on the growth of cucumber seedlings grown in the presence or absence of 2000 ppm NaCl. Biomass production of the plant as (FW g. plant $\left.{ }^{-1}\right)(A)$ and as (DW g. plant ${ }^{-1}$ ) (B). Data presented as means of 5 replicates \pm SD. Bars treatments with different letters are significant different $(P<0.05)$

Selenium improves cucumber seedlings resistance against membrane damage under salinity stress

MDA was taken as a marker for the degree of lipid peroxidation as MDA produced by peroxidation of unsaturated fatty acids in plant cell membrane. (Fig. 2.A) indicates that salinity treatment led to a significant increase in MDA. Whereas, lipid peroxidation of plant tissues increased by salinity treatment about one fold. Treatment of $\mathrm{NaCl}$ treated cucumber seedlings with $1 \mathrm{ppm}$ Se highly reduced the level of lipid peroxidation expressed as MDA content. Moreover, Se treatment reduced content of MDA to the level closed to of untreated cucumber seedling (control). The treatment of Se only caused a slight increase in MDA content about $25 \%$ of control.
To determine the effect of lipid peroxidation on the performance of plant cell, the extend of membrane damage was assessed indirectly by determining the amount of solute leakage from leaf cells. The conductivity measurements presented in (Fig. 2.B) showed that treatment of cucumber seedlings with $2000 \mathrm{ppm} \mathrm{NaCl}$ led to a highly significant increase in the electrolyte leakage. Moreover, the treatment with $\mathrm{NaCl}$ increased the level of EL by about $300 \%$. While, treatment of $\mathrm{NaCl}-$ stressed cucumber seedling with Se caused a high reduction in the electrolyte leakage by about $38 \%$. Moreover, the treatment of Se only caused increased in electrolyte leakage about $76 \%$.

(A)

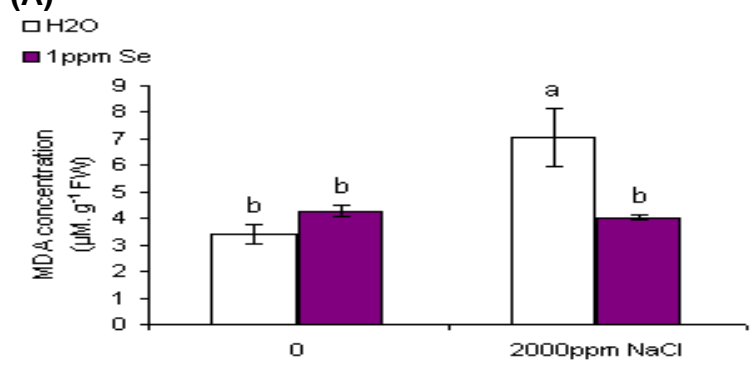

(B)

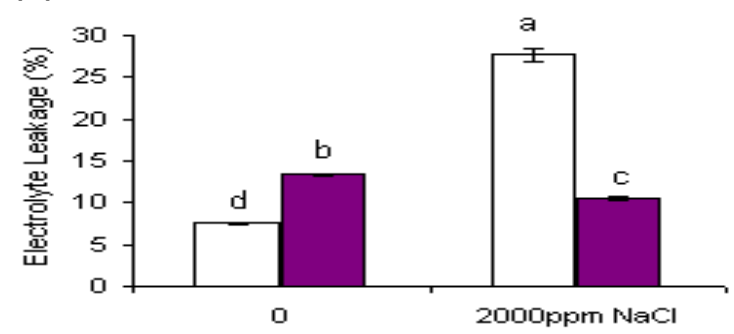

Fig. 2. Effects of Se on lipid peroxidation expressed as malondialdehyde (MDA) concentration ( $\mu \mathrm{Mol}$. $\left.\mathrm{g}^{-1} \mathrm{FW}\right)(\mathrm{A})$ and electrolyte leakage percentage (EL \%) $(B)$ in cucumber seedlings grown in the presence or absence of $2000 \mathrm{ppm}$ $\mathrm{NaCl}$. Data presented as means of 5 replicates \pm SD. Bars treatments with different letters are significant different $(P<0.05)$

Selenium increases the concentration of proline and phenolic compounds in cucumber seedlings grown under salinity stress

Proline and phenols contents were estimated in Se-treated and control cucumber seedlings grown in the presence or absence of salinuty stress. Proline and phenols were increased by $165 \%$ and $118 \%$ respectively by treatment with 2000 ppm $\mathrm{NaCl}$ as compared with control. (Fig.3. A,B). 
The treatment of cucumber seedlings grown under salinity condition with Se caused a significant increase in proline and phenolic compounds contents. Where, Proline content in cucumber seedlings grown under salinity stress increased by about $53 \%$ as a result of treatment with $1 \mathrm{ppm}$ Se. On the other hand, phenolic compounds were increased by about $245 \%$ in salt-stressed cucumber seedling due to Se treatment. In salt-untreated cucumber seedlings (control) Se treatment did not cause significant change in Proline content. While, Phenolic compounds were significantly increased by Se-treatment as compared with control of $\mathrm{cu}$ cumber seedlings. (Fig. 3.B).

(A)

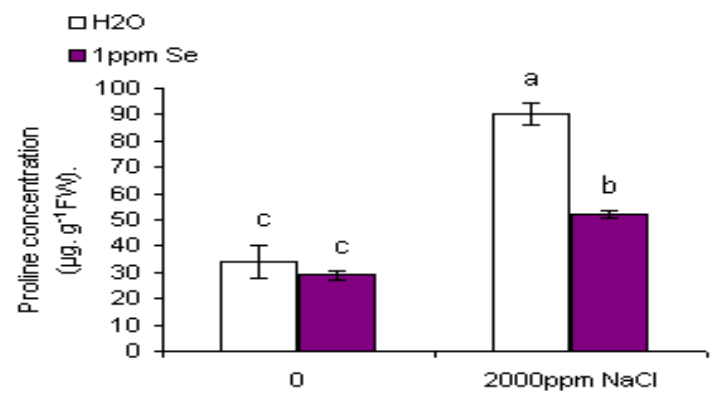

(B)

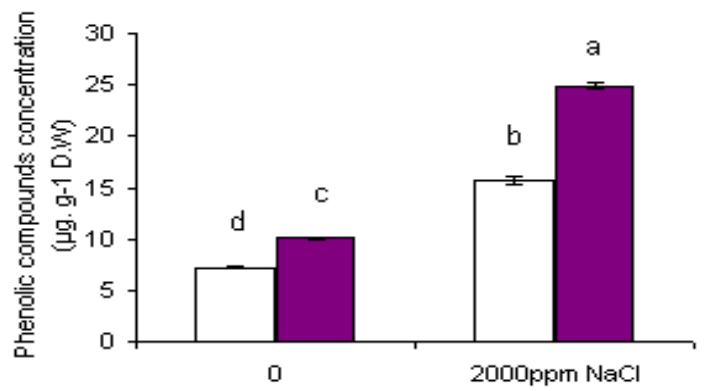

Fig. 3. Effects of Se on Proline concentration ( $\mu \mathrm{g}$. $\mathrm{g}^{-1}$ FW) (A) and Phenolic compounds concentration as $(\mu \mathrm{g}$. catichol $\mathrm{g}^{-1} \mathrm{DW}$ ) (B) in cucumber seedlings grown in the presence or absence of $2000 \mathrm{ppm} \mathrm{NaCl}$. Data presented as means of 5 replicates \pm SD. Bars treatments with different letters are significant different $(P<0.05)$

Se induces the activities of antioxidant enzymes in cucumber seedlings grown under salinity stress

Data in (Fig. 4.A), Showed that salinity stress significantly increased in the specific activity of POD about $110 \%$ of control. Se-treatment caused a significant elevation in specific activity of POD in the presence or absence of 2000ppm NaCl. More- over, Se treatment increased specific activity of POD about $280 \%$ and $120 \%$ of control respectively. CAT activity was decreased in cucumber seedlings irrigated with $2000 \mathrm{ppm} \mathrm{NaCl}$ by about $30 \%$ of control. Se treatment caused a significant increase in the specific activity of catalase in the presence or absence of salinity stress. Moreover, Se treatment increased the specific activity of catalase about $311 \%$ and $220 \%$ of control respectively (Fig. 4.B). Data of SOD activity indicated that salinity stress caused a significant increase in the specific activity of SOD about $20 \%$ of control in cucumber seedlings. Also, Se-treatment caused a significant increase in the specific activity of SOD about $80 \%$ of control in cucumber seedlings irrigated with $2000 \mathrm{ppm} \mathrm{NaCl}$. While, Se treatment of cucumber seedlings grown in non salty medium caused a significant decrease in SOD activity about $15 \%$ of control. But, The irrigation with 2000 $\mathrm{ppm} \mathrm{NaCl}$ in the presence of Se led to a significant elevation in SOD activity (Fig. 4.C). APX activity was significantly increased in cucumber seedlings irrigated with $2000 \mathrm{ppm} \mathrm{NaCl}$ by about $19 \%$ of control. Se treatment caused a significant increase in APX activity in cucumber seedlings grown in the presence or absence of salinity stress. Moreover, Se treatment increased the specific activity of APX ( $65 \%$ and $30 \%$ ) in the presence or absence of 2000 ppm NaCl respectively (Fig.4.D).

Se induces the activity of phenyalanine ammonia-lyase in cucumber seedlings grown under salinity stress

(Fig. 5). Showed that PAL activity was significantly increased in cucumber seedlings which irrigated with 2000 ppm NaCl by about $50 \%$ of control. Se treatment caused a significant increase in PAL activity in cucumber seedlings grown in the presence or absence of salinity stress. Moreover, Se treatment increased the specific activity of PAL (150\% and $90 \%$ ) respectively.

\section{Se up-regulates peroxidase iso-enzymes}

Peroxidase isoforms were analyzed by Native PAGE. POD exist as multiple isoforms (Fig. 6). In the profile of $P O D$ isozymes of control cucumber seedlings Four bands (I,II,IV and V) were detected (lane A). Salinity-treatment and Se-treatment induced the appearance of new band (VI). Also, Setreatment induced the appearance of two new bands (III and VI) were detected (laneD) in cucumber seedlings grown under salinity stress. Whereas, Se caused a quite strong staining intensity in new synthezied bands in salt-stressed cucumber seedlings. Se has a high ability to up-regulate POD isoenzymes (I,III,IV,V and $\mathrm{VI})$ under salty conditions. 
(A)

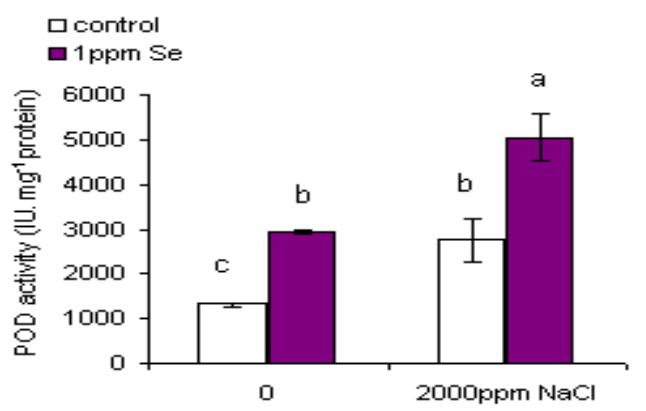

(B)

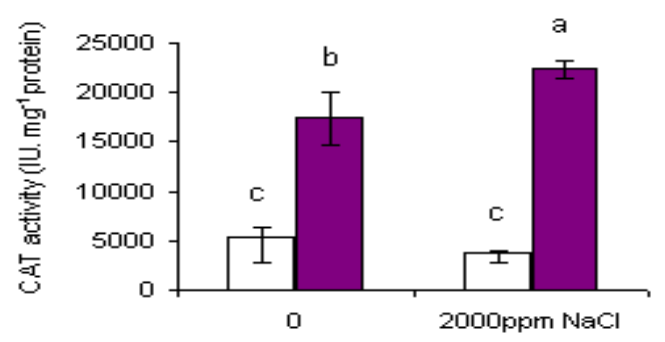

(C)

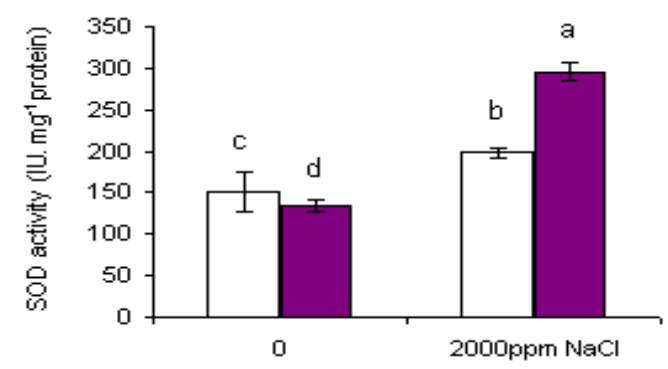

(D)

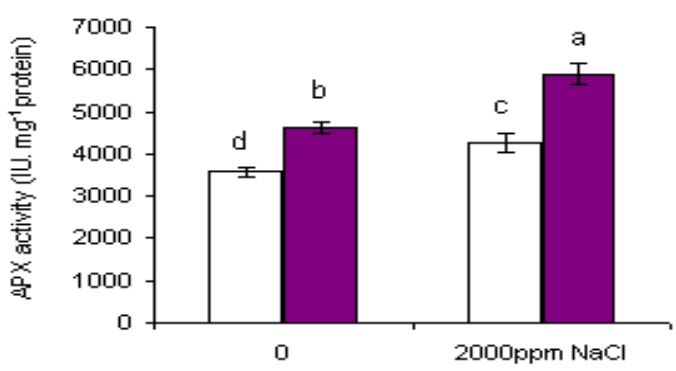

Fig. 4. Effect of selenium on the activities of POD (IU. $\mathrm{mg}^{-1}$ protein) (A), CAT (IU. $\mathrm{mg}^{-1}$ protein) (B), SOD (IU. $\mathrm{mg}^{-1}$ protein) (C) and APX (IU. $\mathrm{mg}^{-1}$ protein) (D) in cucumber seedling grown under salt stress $(2000 \mathrm{ppm} \mathrm{NaCl})$. Data presented as means of 5 replicates \pm SD. Bars treatments with different letters are significant different $(P<0.05)$

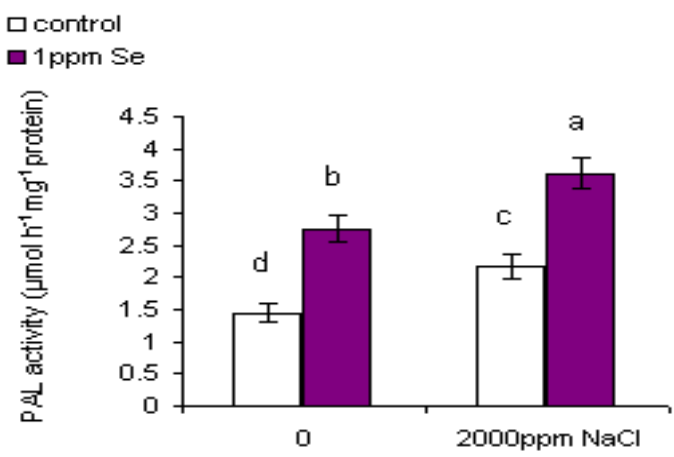

Fig. 5. Effect of selenium on the activity of PAL ( $\mu$ mol. Cinnamic acid $\mathrm{h}^{-1} \mathrm{mg}^{-1}$ protein) in cucumber seedling grown under salt stress $(2000 \mathrm{ppm} \mathrm{NaCl})$. Data presented as means of 5 replicates \pm SD. Bars treatments with different letters are significant different $(P<0.05)$

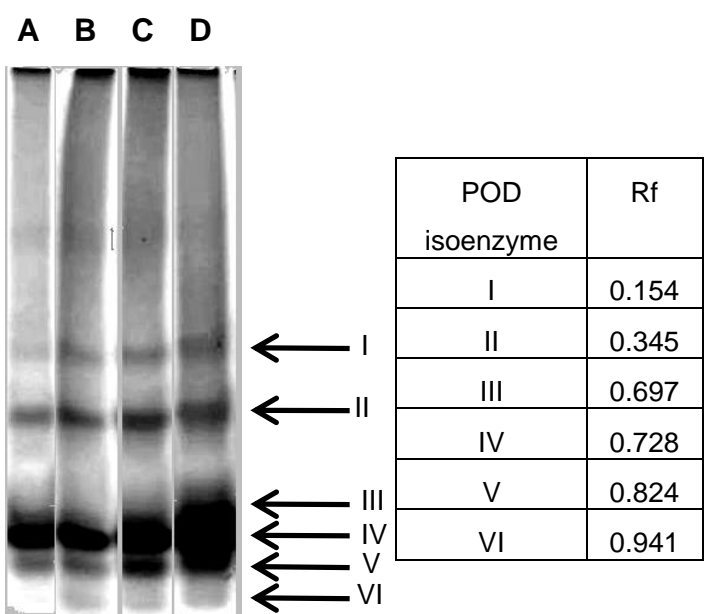

Fig. 6. Effect of Se on peroxidases isoenzymes detected in soluble protein extract from untreated cucumber seedlings (control) (A), Se-treated cucumber seedlings (B), Salt-stressed cucumber seedlings (C) and Se- treated cucumber seedlings grown under salty stress condition (D). Equal amounts of protein $(200 \mu \mathrm{g})$ were loaded from each sample

\section{DISCUSSION}

The production of reactive oxygen species (ROS) is the most important cause of plant cell damage when plants subjected to salt stress, thus leading to growth suppression (Dionisio-Sese and Tobita 1998; Zhu 2001). The observed reduction in the cucumber seedling fresh and dry weight as a result of salinity stress could explaind by the ac- 
cumulation of $\mathrm{H}_{2} \mathrm{O}_{2}$ in plant cells (Fig.1. A,B). Howevere, the accumulation of $\mathrm{H}_{2} \mathrm{O}_{2}$ may lead to increased mechanical strength and lower the extensibility of plant cell walls, which can rapidly reduce seedling growth (Schuiitzendiibel and Polle 2002). Se-treatment caused a significant increase in the fresh and dry weights of cucumber seedlings grown in the presence or absence of salinity stress (Fig.1.A,B). Se at concentration of $1 \mathrm{ppm}$ was able to stimulate the growth of salt-stressed cucumber seedling by increased the antioxidant enzymes activities that reduce the level of accumulation of ROS. Our results are in agreement with previous reports in sorrel seedlings (Kong et al 2005), UVirradiation and senescence related stress in lettuce (Hartikainen and Xue 1999; Xue and Hartikainen 2000 and Pennanen et al 2002), UV-induce stress in reygrass (Hartikainen et al 2000) and photo oxidative stress in potato (Seppänen et al 2003).

The enhanced production of reactive oxygen species in salt stressed seedlings, led to high level of lipid peroxidation and caused a remarkable accumulation of MDA in plant tissues as shown in (Fig. 2.A). The level of MDA, one of the major TBA reactive metabolites, increased in $\mathrm{NaCl}$-treated cucumber seedlings by about two times (Fig. 2.A). The results, we obtained confirmed that $\mathrm{Se}$ is able to reduce the lipid peroxidation in salt stressed seedlings. This protective effect of Se could be attributed to its ability to reduce oxygen radicals that are produced in the presence of salinity stress. Electrolyte leakage is important index of the physiological functions of the cell. Adversities such as drought, salinity and high and low temperatures initially damage the structure of the cell membrane leading to an increase in membrane permeability and resulting in leakage of intracellular contents (Jia et al 2002). Electrolyte leakage is an effective marker of plant cell membrane damage. The observed elevation of lipid peroxidation in saltstressed cucumber seedlings led to a highly significant increased in the level of electrolyte leakage by about 300\% (Fig.2.B). Whereas, Se treatment under salinity stress caused a significant reduction in both electrolyte leakage and MDA concentration. This reduction by Se treatment could be attributed to a high activities of some antioxidant enzymes such as POD and SOD which were highly consistent with the finding of (Gueta-Dahan et al 1997) in citrus and (Dionisio-Sese and Tobita 1998) in rice seedlings.

Many reports indicated that proline accumulated during many biotic and abiotic stress (Aspinall and Paleg 1981; Yoshiba et al 1997; Hare et al
1999 and Chen et al 2001). This response is typical with observed accumulation of proline in saltstressed plant tissues (Fig. 3.A). Treatment of cucumber seedlings grown under salinity condition with Se caused a significant increase in proline content by about $53 \%$ of control. The accumulation of proline in cucumber seedling by salt stress could be explained by increasing biosynthesis or inhibition of proline degradation. Proline biosythensis from glutamate is composed of two enzyme reaction involving $\Delta^{1}$-pyrroline-5-carboxylate synthetase (P5CS) and $\Delta^{1}$-pyrroline-5-carboxylate reductase (P5CR) (Hayashi et al 2000). An increase of P5CR activity by salinity stress was observed in leaves of wheat and P5CS activity did not show a specific response to salinity stress (ZhiQiang et al 2007). Thus, it's obvious that P5CR activity is in tight relation to free proline content. Also, Proline accumulation in plant cells exposed to salt is often considered to be involved in stress resistance mechanisms (Aspinall and Paleg 1981; Yoshiba, et al 1997; Hare et al 1999; Chen et al 2001). Also, Ornithine- $\delta$-aminotransferase (OAT) catalyzes the first step in the pathway of conversion of ornithine to proline (Hare et al 1999). OAT activity was found to increase significantly in detached rice leaves exposed to excess $\mathrm{Cu}$ (Chen et al 2001). The increase in OAT activity may have, to some extent, contributed to the elevated content of proline. Increase in OAT activity along with an increase in the content of proline has also reported in wheat under cold stress (Charest and Phan 1990), and in Brassica juncea under salt stress (Vogel and Kopac 1960). The enzymes proline dehydrogenase (PDH) and $\Delta^{1}$-pyrroline-5carboxylate dehydrogenase (P5CDH) are reported to catalyze proline oxidation (Yoshiba et al 1997 and Hare et al 1999). Activities of thses two enzymes have no effect of CuSO4 stressed in detached rice leaves (Chen et al 2001). These results suggest that proline oxidation (or degradation) contribute little to proline accumulation in detached rice leaves under CuSO4 stress condition. Therefore, the accumulation of proline in cucumber seedling by salt stress could be explained by increasing the activities of (P5CR, P5CS or OAT) or inhibition of proline degradation enzymes $(\mathrm{PDH}$ and $\mathrm{P} 5 \mathrm{CDH}$ ). The effect of Se on the proline level could be due to its effect on one of proline metabolism enzymes and need furthur investigations.

The high phenols content in cucumber seedling treated with $\mathrm{Se}$ in the presence or absence of salinity stress is highly corelated to observed high PAL activities in these seedlings. So, Se enhanced 
the biosynthesis of phenolic compounds by induction the activity of PAL which catalyzed the formation of trans-cinnamic acid by deamination of L-Phenylalanine. The production of transCinnamic acid acts as the primer intermediary step in the biosynthesis of phenolic compounds (Kacperska 1993; Dixon et al 1992; Rosler et al 1997 and Rivero et al 2001). Oxidation of phenolic compounds by polyphenol oxidase and peroxidase in leaves leads to the production of quinones (Thypyapong et al 1995) which responsible for the production of active oxygen species under oxidative stress (Pillinger et al 1994).

ROS generated due to salinity stress unbalances the cellular redox system in favor of oxidized forms resulting in oxidized damage to lipids, proteins and nucleic acids. So, plants adapted different protective mechanism to scavenge the free radicals produced under oxidative stress. In the present study, salinity stress resulted in a significant increase in the specific activities of (POD, $S O D, A P X$ and $P A L)$ and a significant decrease in CAT activity in cucumber seedlings. This response indicates that enhanced production of free radicals under salinity sressed condition. Similar results have been found in $\mathrm{NaCl}$-stressed roots of chrysanthemum (Hossain et al 2004) and Cdstressed in Rape seedlings (Filek et al 2007; Rout and Shaw 2001). Se treatment caused a significant elevation in the specific activities of antioxidant enzymes (POD, CAT, SOD and APX) and PAL either $\mathrm{NaCl}$-treated cucumber seedlings which indicate that Se can increase the tolerance of plants against oxidative stress (Fig.4,5). This protective effect of Se has been demonstrated as a known action of its antioxidant effect because it forms selenocysteine, part of the active center of antioxidant enzymes (Levander and Burk 1994) and as an increase in the activity of antioxidative enzymes (Xue et al 2001 and Sappänen et al 2003). Also. the present study showed that the specific activity of SOD was slightly reduced by Se treatment of control seedlings which indicate that Se may enhance the spontaneous disproportion of superoxide radicals and thus reduce the need of their scavenger SOD (Hartikainen et al 2000). The induction of individual isozymes to salinity stres is interpreted as a response to augmented ROS generation. Both of salt treatment and Setreatment exert differential effects on the expression of the multiple forms of POD (Fig.6). The salttreated plants were capable of synthesizing new isoform of POD, which could be considered as a response to salinity-induced oxidative damage.
The results suggested that enzymatic removal of $\mathrm{H}_{2} \mathrm{O}_{2}$ by $\mathrm{POD}$ is the domainant pathway during salinity stress. Also, new synthezied isoforms of POD were detected in plants treated with $\mathrm{Se}$ in the presence of salinity stress. Whereas, Se enhanced POD activity because it forms selenocysteine, part of the active center of peroxidase (Levander and Burk 1994). The increased in peroxidase denisty and intensity in both of Se treatments could be a result of increasing the expression of POD genes.

The protective role of Se on the salt stress in cucumber seedlings could be due to : (1) reduction of oxygen radicals, (2) osmotic regulation by synthesis of osmoregulatory compound such as proline, (3) increasing the biosynthesis of nonenzymatic antioxidants such as phenols by increasing the activity of PAL and (4) induction the activities of some antioxidant enzymes and biosynthesis of new peroxidase isozymes.

\section{REFERENCES}

A.O.A.C. (1975). Official Method of Analysis (10 ${ }^{\text {th }}$ Ed.), Association Agriculture Chemists, Washington, D.C, U.S.A.

Aeby, H. (1984). Catalase in vitro. Meth. Enzymol. 105: 121-126.

Alscher, R.G.; J.L. Donahue and C.L. Cramer (1997). Reactive oxygen species and antioxidants: relationships in green cells. Physiol. Plant. 100: 224-233.

Aspinall, D. and L.G. Paleg (1981). Proline accumulation: physiological aspects. In: Paleg, L. G. and D. Aspinall.(eds.), The Physiology and Biochemistry of Drought Resistance in Plants (pp. 205-241), Academic Press, Sydney.

Beauchamp, C. and I. Fridovich (1971). Superoxide dismutase: improved assays and an assay applicable to acrylamide gels. Anal. Biochem. 44: 276-287.

Charest, C. and C.T. Phan (1990). Cold acclimation of wheat (Triticum aestvum): properties of enzymes involved in proline metabolism. Physiol. Plant. 80: 159-168.

Chen, C.T.; C.L. Men; C.C. Lin and C.H. Kao (2001). Regulation of proline accumulation in detached rice leaves exposed to excess copper. Plant Sci. 160: 283-290.

Dionisio-Sese, M.L. and S. Tobita (1998). Antioxidant responses of rice seedlings to salinity stress. Plant Sci. 135: 1-9.

Dixon, R. A.; A.D. Choudhary; D. Dalkin; R. Edwards; T. Fahrendorf; G. Gowri; M.J. Harrison; C.J. Lamb; G.J. Loake; C.A. Maxwell; J. Orr and 
N.L. Paiva (1992). Molecular biology of stressinduced phenylpropanoid and isoflavonoid biosynthesis in alfalfa. In: Stafford, H.A. and R.K. Ibrahim (eds.), Phenolic Metabolism in Plants (pp. 91138), Plenum Press, New York.

Egert, M. and M. Tevini (2002). Influence of drought on some physiological parameters symptomatic for oxidative stress in leaves of chives (Allium schoenoprasum). Env. Exp. Bot. 48: 43-49.

Fieldes, M. A. and K.E. Gerhardt (1998). Flax guaiacol peroxidase can be used to illustrate the possibility of misinterpreting the effect of stress on the activity of developmentally regulated enzymes. Plant Sci. 132: 89-99.

Filek, Maria; Rùcka Keskinen; Helina Hartikainen; Iwona Szarejko; Agnieszka Janiak; Zbigniew Miszalski and Agnieszka Golda (2007). The protective role of selenium in rape seedlings subjected to cadmium stress. J. Plant Physiology. 165: 833-844.

Gueta-Dahan, Y.; Z. Yaniv; B.A. Zilinskas and G. Ben-Hayyim (1997). Salt and oxidative stress: similar and speciefic responses and their relation to salt tolerance in Citrus. Planta 203: 460-469.

Halliwell, B. and J.M.C. Gutteridge (1989). Free Radicals in Biology and Medicine (Second Edn.), Clarendon Press, Oxford, UK.

Hammer Schmidt, R.; E.M. Nuckles and J. Kuc (1982). Association of enhanced peroxidase activity with induced systemic resistance of cucumber to colletotrichum lagenarium. Physiol. Plant. 20: 7382.

Hare, P.D.; W.A. Cress and J. Van Staden (1999). Proline synthesis and degradation: a model system for elucidating stress related signal transduction. J. Exp. Bot. 50: 413-434.

Hartikainen, H. and T. Xue (1999). The promotive effect of selenium on plant growth as trigged by ultraviolet irradiation. J. Environ. Qual. 28: 12721275.

Hartikainen, H.; P. Ekholm; V. Piironen; T. Xue; T. Koivu and M. Yli-Halla (1997). Quality of the ryegrass and lettuce yields as affected by selenium fertilization. Agric. Food Sci. Finland 6: 381-387. Hartikainen, H.; T. Xue and V. Piironen (2000). Selenium as an antioxidant and pro-oxidant in ryegrass. Plant Soil 225: 193-200.

Hasegawa, P.M.; R.A. Bressan; J.K. Zhu and H.J. Bohnert (2000). Plant cellular and molecular responses to high salinity. Annual. Rev. Plant Physiol. Plant Mol. Biol. 51: 463-499.

Hayashi, F.; T. Ichino; M. Osanai and K. Wada (2000). Oscillation and regulation of proline content by $\mathrm{P} 5 \mathrm{CS}$ and proDH gene expressions in the light/dark cycles in Arabidopsis thaliana L. Plant Cell Physiol 41: 1096-1001.

He, C.Y.; T. Hsiang and D.J. Wolyn (2001). Activation of defense responses to Fusarium infection in Asparagus densiflorus. European Journal of Plant Pathology 107: 473-483.

Heath, R.L. and L. Packer (1968). Photoperoxidation in isolated chloroplasts. 1. Kinetics and stoichiometry of fatty acids peroxidation. Arch. Biochem. Biophys. 125: 189-198.

Hossain, Zahed; Abul Kalam Azad Mandal; Ratnakar Shukla and Subodh Kumar Datta (2004). $\mathrm{NaCl}$ stress-its chromotoxic effects and antioxidant behavior in roots of Chrysanthemum morifolium Ramat. Plant Sci. 166: 215-220.

Janoudi, A.K. and I.E. Widders (1993). Water deficits and fruiting affect carbon assimilation and allocation in cucumber plants. Hort. Science 28: 98-100.

Jia, G.X.; Z.Q. Zhu; F.Q. Chang and Y.X. Li (2002). Transformation of tomato with the BADH gene from Atriplex improves salt tolerance. Plant Cell Rep. 21: 141-146.

Kacperska, A. (1993). Water potential alteration: A prerequisite or a triggering stimulus for the development of freezing tolerance in over wintering herbaceous plants. In: Li, P.H; L. Christerson (eds.), Advances in Plant Cold Hardiness (pp. 73-91), CRC Press, Boca Raton.

Kong, L.; M. Wang and D. Bi (2005). Selenium modulates the activities of antioxidant enzymes, osmotic homeostasis and promotes the growth of sorrel seedlings under salt stress. Plant Growth Regulation. 45: 155-163.

Levander, O.A. and R.F. Burk (1994). Selenium. In: Modern Nutrition in Health and Disease (pp. 242-251), Shils, M.E.; J.A. Olson and M. Shike (eds.), Lea and Febiger, Philadelphia.

Levine, A.; R. Tenhaken; R. Dixon and C. Lamb (1994). $\mathrm{H}_{2} \mathrm{O}_{2}$ from the oxidative burst orchestrates the plant hypersensitive disease resistance response. Cell 79: 583-593.

Leyva, A.; J.A. Jarrillo; J. Salinas and M. Martínez-Zapater (1995). Low temperature induces the accumulation of phenylalanine ammonia-lyase and chalcone synthase mRNA of Arabidopsis thaliana in light-dependent manner. Plant Physiol. 108: 39-46.

Lowry, O.H.; N.J. Roenbrough; A.L. Farr and E.J. Randal (1951). Protein measurement with the folin phenol reagent. J. Biol. Chem. 193: 265275.

Nakano, Y. and K. Asada (1981). Hydrogen peroxide is scavenged by ascorbatespecific peroxi- 
dase in spinach chloroplasts. Plant Cell Physiol. 22: 867-880.

Olmos, E.; A. Piqueras; J.R. Marttinez-Solano and E. Hellin (1997). The subcellular localization of peroxidase and the implication of oxidative stress is hyper hydrated leaves of regenerated carnation plants. Plant Sci. 130: 97-105.

Pennanen, A.; T. Xue and H. Hartikainen (2002). Protective role of selenium in plant subjected to severe UV irridiation stress, J. Appl. Bot. 76: 6676.

Petters, W.; M. Piepenbrock; B. Lenz and J.M. Schmitt (1997). Cytokinine as a negative effector of phosphoenolpyruvate carboxylase induction in Mesembryanthemum crystallinum. J. Plant Physiol. 151: 362-367.

Pillinger, J. M.; J.A. Coope and I. Ridge (1994).

Role of phenolic compounds in the antialgal activity of barley straw. J. Chem. Ecol. 20: 1557-1569.

Rao, M.V.; G. Paliyath; D.P. Ormrod; D.P. Murr and C.B. Watkins (1997). Influence of salicylic acid on $\mathrm{H}_{2} \mathrm{O}_{2}$ production, oxidative stress and $\mathrm{H}_{2} \mathrm{O}_{2}$-metabolizing enzymes: salicylic acidmediated oxidative damage requires $\mathrm{H}_{2} \mathrm{O}_{2}$, Plant Physiol. 115: 137-149.

Rivero, Rosa M.; Juan M. Ruiz; Pablo C. Garcı'a; Luis R. Lo'pez-Lefebre; Esteban Sa'nchez and Luis Romero (2001). Resistance to cold and heat stress: accumulation of Phenolic compounds in tomato and watermelon plants. Plant Sci. 160: 315-321.

Rosler, J.; F. Krefel; N. Amrhein and I. Sohmid (1997). Maize phenylalanine ammonia-lyase activity, Plant Physiol. 113: 175-179.

Rout, N.P and B.P. Shaw (2001). Salt tolerance in aquatic macrophytes: possible involvement of the antioxidative enzymes. Plant Sci. 160: 415-423.

Sancho, M.A.; S. Milrad de Forchetii; F. Pliego; V. Valpuesta and M.A. Quesada (1996). Total peroxidase activity and isoenzymes in the culture medium of $\mathrm{NaCl}$ adapted tomato suspension cells. Plant Cell Tiss. Org. Cult. 44: 161-167.

Schuiitzenduiibel, A. and A. Polle (2002). Plant responses to abiotic stresses: heavy metalinduced oxidative stress and protection by mycorrhization. J. Exp. Bot. 53: 1351-1365.

Seppänen, M.; $\mathbf{M}$. Turakainen and $\mathbf{H}$. Hartikainen (2003). Selenium effects on oxidative stress in potato. Plant Sci. 165: 311-319.
Shahidi, F. and M. Naczk (1995). Methods of analysis and quantification of phenolic compounds. Food phenolic: Sources, Chemistry, Effects and Applications (pp. 287-293). Technomic Publishind Company, Inc., Lancaster.

Sigel, B. (1993). Plant peroxidases an organismic perspective. Plant Growth Regul. 12: 303-312.

Smirnoff, N. (1993). The role of active oxygen in the response of plants to water deficit and desiccation. New Phytol. 125: 27-58.

Thypyapong, P.; M.D. Hunt; J.C. Steffens (1995). Systemic wound induction of potato (Solanum tuberosum) polyphenol oxidase. Phytochemistry 40: 673-676.

Trelease, S.F. and H.M. Trelease (1990). Selenium as a stimulating and possible essential element for certain plants. Science 15: 57-58.

Vogel, R.H. and M.J. Kopac (1960). Some properties of ornithined-transaminase from Neurospore, Biochem. Biophys. Acta 37: 539-540.

Xue, T.; H. Hartikainen (2000). Association of antioxidative enzymes with the synergistic effect of selenium and UV irradiation in enhancing plant growth, Agric. Food Sci. Finland 9: 177-186.

Xue, T.; H. Hartikainen and V. Piironen (2001). Antioxidative and growth-promoting effect of selenium in senescing lettuce, Plant Soil 237: 55-61.

Yordanov, I.; V. Velikova; T. Tsonev (2000). Plant responses to drought, acclimation, and sress tolerance. Photosynthetica 38: 171-186.

Yoshiba, Y.; T. Kiyosue; K. Nakashima; K. Yamaguchi-Shinozaki and K. Shinozaki (1997). Regulation of levels of Proline as an osmolyte in plants under water stress, Plant Cell Physiol. 38: 1095-1102.

Zhi-Qiang Wang; Yong-Ze Yuan; Ji-Quan Ou; Qing-Hua Lin and Chu-Fu Zhang (2007). Glutamine synthetase and glutamate dehydrogenase contribute differentially to proline accumulation in leaves of wheat (Triticum aestivum) seedlings exposed to different salinity. J. of Plant Physiology 164: 695-701.

Zhou, M.H. (1990). Influence of Selenium on growth root vigor and seed morphology of rice. Agri. Sci. 15: 57-59.

Zhu, J.K. (2001). Plant salt tolerance. Trends Plant Sci. 6: 66-71. 